\title{
The Influence of Corporate Governance Mechanism against Fraud in Financial Statements
}

\author{
Sely Megawati Wahyudi ${ }^{*}$, Riaty Handayani, Wieta Chairunesia
}

Accounting Study Program, Faculty of Economics and Business, Mercu Buana University, Jl. Raya Meruya Selatan No. 1, Meruya Selatan, Kembangan, West Jakarta, Daerah Khusus Ibukota Jakarta 11650, Indonesia

\author{
DOI: $10.36348 /$ sjef.2019.v03i12.003 \\ | Received: 19.12.2019 | Accepted: 26.12.2019 | Published: 30.12.2019 \\ *Corresponding author: Sely Megawati Wahyudi
}

\section{Abstract}

This study aims to determine the effect of corporate governance mechanisms on fraud in financial reporting. The sampling technique used was purposive sampling. This research was conducted at non-financial companies with a research time period (2015-2017). The estimated model used is logistic regression analysis. The purpose of this study is to determine whether corporate governance mechanisms influence fraud in financial reporting. This research involves 2 (two) variables consisting of 1 (one) dependent variable, 2 (two) independent variables. The dependent variable in this study is fraud in financial reporting. The independent variables in this study are the audit committee and leverage. The results of the research conducted in the regression analysis are $11.5 \%$ of the corporate governance mechanism variables against fraud in financial reporting. This means that corporate governance mechanisms simultaneously influence fraud in financial reporting.

Keywords: Corporate Governance Mechanism, Audit Committee, Fraud in Financial Reporting.

Copyright @ 2019: This is an open-access article distributed under the terms of the Creative Commons Attribution license which permits unrestricted use, distribution, and reproduction in any medium for non-commercial use (NonCommercial, or CC-BY-NC) provided the original author and source are credited.

\section{Preliminary RESEARCH BACKGROUND}

Changes in financial reporting will certainly have an adverse effect, because society in general measures the success of the company based on its performance. One of the company's performance can be seen based on financial statements that provide financial information about operating activities and the company's financial position [1]. The performance appraisal encourages management to carry out the company's operational activities to the full, so as to provide information to stakeholders that the company is in a healthy condition. However, efforts made by management tend to lead to fraud in financial reporting. This causes the information in the financial statements to be irrelevant to stakeholders as a basis for decision making [2].

Other research, namely the Implementation of Good Corporate Governance and Voluntary Disclosure Compliance: the 100-20 compass indexes of the 20152016 listed Indonesian stock exchange (IDX) companies conducted by Rieke Pernamasari [3] showed that institutional ownership had a positive effect on voluntary disclosure while proportion the board of commissioners with accounting or business skills, and the proportion of audit committees with accounting or business skills have a significant negative influence on voluntary disclosure and other variables namely the proportion of independent commissioners, board of commissioners meetings, frequency of audit committee meetings and the proportion of independent audit committees that have no effect on voluntary disclosure.

Fraud in financial reporting is very dangerous because it can caused by 1) damage the reliability, quality, materiality and integrity of the financial reporting process, 2) endanger the integrity and objectivity of the audit profession, especially external auditors and internal auditors, 3) reduce capital market confidence, like a market share on financial reliability, 4) capital markets become less efficient, and 5) the impact of economic growth and national prosperity is reduced [4]. Fraudulent financial reporting is the presentation and deliberate disclosure made by management with the aim to deceive the users of financial statements. Increased fraud in financial reporting in public companies, has also increased the concerns of users of financial statements such as auditors, investors, creditors [2]. Reporting fraud includes, firstly, the manipulation, falsification or alteration of accounting records or supporting 
documents which are the source of data for the presentation of financial statements. Both misrepresentations or omissions from financial statements of significant events, transactions or information. Third, the deliberate misapplication of accounting principles related to the number of classifications and methods of disclosure [5].

An independent commissioner is a body within a company that usually consists of an independent board of commissioners from outside the company whose function is to assess the overall and overall performance of the company [6]. Independent commissioners generally have better oversight of management, thereby affecting the possibility of fraud in presenting financial reports by managers [7]. That is, the more independent the board of commissioners, the more it will reduce fraud in financial reporting.

Research conducted by Utomo [8] examines corporate governance in detecting fraudulent financial reporting. The results of the study show that directly the ownership structure with a proxy for foreign ownership, domestic ownership and public ownership has a negative and significant impact on financial statement fraud. However, firm size proxied by total assets has a significant positive effect on financial statement fraud. After being moderated with total assets, the stronger and more negative the structure of ownership with the proxy of foreign ownership, domestic ownership and public ownership of fraud financial statements.

\section{Identification of Problems}

From the background described above, it can be identified the problem that will be examined in relation to the phenomenon of the problem, is there an influence of corporate governance mechanisms on fraud in financial reporting?

\section{Formulation of the Problem}

Based on the background that has been described, the problem formulation in this study is there an influence of corporate governance mechanisms on fraud in financial reporting?

\section{Research Purposes}

The purpose of this study is to determine the effect of corporate governance mechanisms on fraud in financial reporting.

\section{LITERATURE REVIEW, FRAMEWORK AND HYPOTHESES LITERATURE REVIEW Corporate Governance}

While Agency Theory, which was developed by Micheal Johson, sees that the company's management as an "agent" for shareholders will act with awareness for their own interests, not as a wise and prudent and fair party to shareholders. In the development of agency theory received a broader response because it is seen to better reflect the existing reality. Various thoughts about corporate governance develop by relying on agency theory where management is carried out in full compliance with various applicable rules and regulations.

Good corporate governance (GCG) is definitively a system that regulates and controls companies that create added value for all stakeholders. There are two things that are emphasized in this concept, firstly the importance of the right of shareholders to obtain information correctly and in a timely manner and secondly the company's obligation to disclose accurately, timely, transparent to all information on company performance, ownership, and stakeholders.

\section{Audit Committee}

An audit committee is a body formed in a client company whose job is to maintain the independence of the auditor's accountant towards management [9]. The audit committee functions to provide views on issues relating to financial policy, accounting and internal control. The purpose of forming an audit committee is: Ensuring that the financial statements issued are not misleading and in accordance with generally accepted accounting practices. Ensuring that internal controls are adequate. Following up on allegations of material irregularities in the financial sector and their legal implications. Recommend internal auditor selection [10].

The audit committee is tasked with assisting the board of commissioners to monitor the financial reporting process by management to increase the credibility of financial statements $[11,12]$. The duties of the audit committee include reviewing the accounting policies adopted by the company, assessing internal control, reviewing the external reporting system and compliance with regulations. In carrying out their duties the audit committee provides formal communication between the board, management, external auditors and internal auditors $[11,12]$. Formal communication between the audit committee, internal auditor and external auditor will ensure that the internal and external audit processes are carried out properly. A good internal and external audit process will increase confidence in the financial statements $[13,12]$.

\section{Leverage}

Companies that have high leverage ratios as a result of the large amount of debt compared to the assets owned by the company, are suspected of cheating because the company is threatened to not be able to meet debt obligations on time [2]. Therefore, when a company has a high leverage ratio, it creates the possibility for fraudulent financial reporting by the directors and management of the company by reducing their leverage ratio in order to achieve their interests, 
namely obtaining loans again and to pay dividends to shareholders [1].

\section{Fraud in Financial Reporting}

The definition of financial reporting fraud according to the American Institute Certified Public Accountant 1998 is a deliberate act or omission which results in material misstatement that misleads the financial statements. In addition, according to the Australian Auditing Standards (AAS), financial reporting fraud is a negligence or intentional misinterpretation of a certain amount or disclosure in financial reporting to deceive users of financial statements $[14,1]$.

Nguyen [15] in Wicaksono [2] explains that fraud in financial statements involves schemes such as the following:

1. Counterfeiting, alteration or manipulation of material financial records, supporting documents or business transactions.

2. Deliberate negligence or transactions, accounts or other important information from the financial statements prepared.

3. Intentional errors in the use of accounting principles, policies and procedures used to measure, recognize, report and disclose economic events and business transactions.

4. Intentional negligence on the disclosure or presentation of inadequate disclosures based on accounting principles and related financial policies and values.

\section{Research Variable \\ Corporate Governance Mechanism}

Corporate Governance Mechanism is a structure and mechanism that regulates company management so as to produce long-term sustainable economic value for shareholders and stakeholders. The indicators used in this study are audit committee and leverage.

\section{Fraud in Financial Reporting}

This variable is measured by using a dummy variable which is categorized into two, namely code 1 (one) for companies that are proven to have committed fraud (fraud) and code 0 (zero) for companies that have not committed fraud (non-fraud).

\section{Previous Research}

Research conducted by Utomo [8] examines corporate governance in detecting fraudulent financial reporting. The results of the study show that directly the ownership structure with a proxy for foreign ownership, domestic ownership and public ownership has a negative and significant impact on financial statement fraud. However, firm size proxied by total assets has a significant positive effect on financial statement fraud. After being moderated with total assets, the stronger and more negative the structure of ownership with the proxy of foreign ownership, domestic ownership and public ownership of fraud financial statements.

Razali and Arshad [16] examine the relationship between the structure of corporate governance and the possibility of fraudulent financial reporting. The results of this study indicate that there is a significant negative relationship between the audit committee, the effectiveness of the internal audit and the independent board of commissioners on the possibility of fraud in financial reporting. However, the size of the board of commissioners and experienced international board members does not significantly influence the possibility of fraud in financial reporting.

\section{Framework}

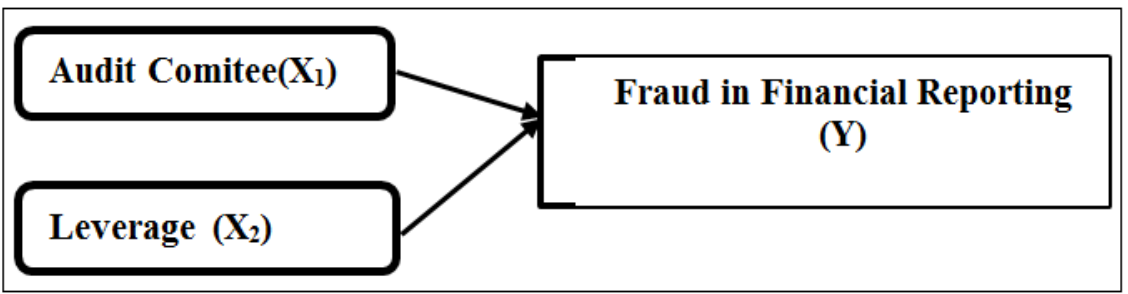

\section{RESEARCH METHODS}

\section{Population and Research Samples}

The population used in this study is NonFinancial companies during the study period (20152017). The data used in this study for the 2015-2017 period is due to the fact that this data is the latest data available during the study. The sample is part of the population that is expected to represent its characteristics. The research sample is determined based on purposive sampling which means the selection of samples is based on certain criteria.

\section{Data Analysis Method}

Data analysis was performed using logistic regression analysis covering the following analysis:

\section{Overall Model Fit}

This test is used to test simultaneously the effect of independent variables on the dependent variable. The first step is to overal fit the model for data. Some statistical tests are given to assess this. The hypothesis for assessing model fit is [17]:

H0: The hypothesized model is fit with the data

HA: The hypothesized model does not fit the data 
From this hypothesis it is clear that we will not reject the null hypothesis so that the model is fit with the data. The statistics used are based on the likelihood function. Likelihood $\mathrm{L}$ of the model is the probability that the hypothesized model represents the input data. To test the null and alternative hypotheses, $\mathrm{L}$ is transformed into -2LogL.

\section{Goodness of Fit Test}

The accuracy of the sample regression function in estimating the actual value can be measured from the Goodness of Fit Test [18]. This test is carried out using the statistical value of the Hosmer and Lemeshow Test to test the null hypothesis and obtain evidence that the empirical data used is in accordance with the model.

If the statistical value of the Hosmer and Lemeshow Test is significant or smaller than 0.05, then the null hypothesis is rejected and the model is deemed unfit. However, if the statistical value of the Hosmer and Lemeshow Test is greater than 0.05, then the null hypothesis is accepted and means that the model is able to predict its observational value or the model can be said to be in accordance with its observational data.

\section{Coefficient of Determination (Cox and Snell $R$ Square dan Nagelkerke's R Square)}

The coefficient of determination is overview which states how well the sample regression line matches the data. Tests carried out to measure how much power the independent variable can explain the dependent variable. The coefficient of determination is 0 and 1 . A small $R^{2}$ value means that the ability of the independent variables to explain the independent variables is very limited. A value close to 1 means that the independent variables provide almost all the information needed to predict the dependent variable [18].

\section{Hypothesis Testing}

This test is carried out to test how far all the independent variables entered in the model are able to influence the dependent variable. This test is performed using a significance level of $0.05(\alpha=5 \%)$. Acceptance or rejection of the hypothesis is carried out with the following criteria:
- If the significant value is greater than 0.05 then the hypothesis is rejected (the regression coefficient is not significant). This means that partially the independent variable does not have a significant effect on the dependent variable.

- If the significant value is less than 0.05 then the hypothesis is accepted (significant regression coefficient). This means that partially the independent variable has a significant effect on the dependent variable.

\section{RESEARCH RESULTS AND DISCUSSION Hypothesis Testing and Discussion Goodness of Fit Test}

The accuracy of the sample regression function in estimating the actual value can be measured from the Goodness of Fit Test [18]. This test is carried out using the statistical value of the Hosmer and Lemeshow Test to test the null hypothesis and obtain evidence that the empirical data used is in accordance with the model. Where is the hypothesis Ho: Eligible Model and H1: Model is not feasible.

\begin{tabular}{|r|r|r|r|}
\hline \multicolumn{4}{|c|}{ Hosmer and Lemeshow Test } \\
\hline Step & Chi-square & df & Sig. \\
\hline 1 & 8,887 & 8 &, 352 \\
\hline
\end{tabular}

From the table above it can be seen that the Sig value is 0.352 which means that the model of this test is feasible because the Sig value $>0.05$ then the null hypothesis is accepted and means that the model is able to predict the value of the observations or the model can be said to be in accordance with the observational data.

\section{Coefficient of Determination (Cox and Snell $R$ Square dan Nagelkerke's $R$ Square)}

The coefficient of determination is an overview that states how well the sample regression line matches the data. Tests carried out to measure how much power the independent variable can explain the dependent variable. The coefficient of determination is 0 and 1 . A small $\mathrm{R}^{2}$ value means that the ability of the independent variables to explain the independent variables is very limited. A value close to 1 means that the independent variables provide almost all the information needed to predict the dependent variable [18].

\begin{tabular}{|r|r|r|r|}
\hline \multicolumn{3}{|c|}{ Model Summary } \\
\hline Step & -2 Log likelihood & Cox \& Snell R Square & Nagelkerke R Square \\
\hline 1 & $81,893^{\text {a }}$ &, 083 &, 115 \\
\hline \multicolumn{2}{|r|}{ a. Estimation terminated at iteration number 4 because parameter estimates changed by less than, 001.} \\
\hline
\end{tabular}

From the table above, the Nagelkerke $\mathrm{R}$ Square value shows the coefficient of determination. The value can be 0.115 , which means $11.5 \%$ of the influence of all independent variables on the dependent variable, where the only significant influence is the audit committee and leverage variables.

\section{Hypothesis Testing}

This test is carried out to test how far all the independent variables entered in the model are able to influence the dependent variable. This test is performed using a significance level of $0.05(\alpha=5 \%)$. 


\begin{tabular}{|c|c|c|c|c|c|c|c|c|c|}
\hline \multicolumn{10}{|c|}{ Variables in the Equation } \\
\hline & & \multirow[t]{2}{*}{ B } & \multirow[t]{2}{*}{ S.E. } & \multirow[t]{2}{*}{ Wald } & \multirow[t]{2}{*}{ df } & \multirow[t]{2}{*}{ Sig. } & \multirow[t]{2}{*}{$\operatorname{Exp}(B)$} & \multicolumn{2}{|c|}{ 95\% C.I.for EXP(B) } \\
\hline & & & & & & & & Lower & Upper \\
\hline \multirow[t]{3}{*}{ Step $1^{\mathrm{a}}$} & KomAud &,- 015 & ,022 & ,473 & 1 & ,492 & 985 & ,943 & 1,028 \\
\hline & Leverage &,- 774 & ,350 & 4,882 & 1 & 027 & ,461 & 232 & 916 \\
\hline & Constant & 2,001 & ,693 & 8,330 & 1 &, 004 & 7,396 & & \\
\hline
\end{tabular}

From the table above, it can be seen that the variables that influence the financial statement fraud include leverage $(0.027)$ because $<0.05$ while the audit committee variable (0.492) does not affect the financial statement fraud. While the value of $\operatorname{Exp}$ (B) to determine the type of influence on the variables that have a significant effect. If the value is below "1", it means the risk is greater for financial statement fraud. Exp (B) on the audit committee (0.985) and leverage $(0.461)$ tend to be at risk of financial statement fraud.

\section{DISCUSSION}

From the above analysis it can be concluded that Sig $>0.05$ is seen which means there is no influence between the audit committee with fraud in financial reporting. Different results with Razali and Arshad's [19] study examined the relationship between the structure of corporate governance and the likelihood of fraudulent financial reporting. The results of this study indicate that there is a significant negative relationship between the audit committee, the effectiveness of the internal audit and the independent board of commissioners on the possibility of fraud in financial reporting.

From the above analysis it can be concluded that Sig $<0.05$ is seen which means there is an influence between leverage and fraud in financial reporting.

\section{CONCLUSIONS AND SUGGESTIONS CONCLUSION}

Logistic Regression Testing is done to see the effect of the independent variable with the dependent variable. The logistic regression equation results obtained are:

$$
\mathrm{Y}=2,001-0,015 \mathrm{X} 1-0,774 \mathrm{X} 2+\mathrm{e}
$$

The regression equation shows that there is a negative relationship between the audit committee on fraud in financial reporting and a negative relationship between leverage and fraud in financial reporting. A negative relationship means that the movement of the audit committee and leverage is not going in the same direction, when the audit committee and leverage increase, resulting in a decrease in fraud in financial reporting and vice versa.

The coefficient of determination test results obtained by the value of $\mathrm{R}$ Square $=0.115$. This shows that $11.5 \%$ of the cheating variables in financial reporting are influenced by independent variables namely the audit committee and leverage. While the rest is explained by other factors. Hypothesis testing is done to determine the effect of each variable individually (each) on the dependent variable. Audit committee level variables have a significant level of $0.492>0.05$, this means that $\mathrm{H}$ is accepted. So, it can be concluded that the audit committee does not have a significant influence on fraud in financial reporting. The leverage level variable has a significant level of 0.027 $<0.05$, this means that $\mathrm{H}$ is rejected. So, it can be concluded that leverage has a significant effect on fraud in financial reporting.

\section{SUGGESTION}

Some suggestions that can be stated in the results of this study are due to imperfections of research conducted by the author, the authors provide suggestions that are expected to be able to gain knowledge from this research, as follows:

- Further research is needed to be able to find out more things that affect fraud in financial reporting in addition to the audit committee and leverage.

- Research time should be made long, so that it can provide a better picture. Because the results are likely to be different when using different periods.

- For investors it is better to make leverage as one of the references in making policies to invest in the capital market.

\section{REFERENCES}

1. Ansar, M. (2013). Analisis Faktor-Faktor Yang Mempengaruhi Kecurangan Pelaporan Keuangan Pada Perusahaan Publik Di Indonesia. Universitas Diponegoro Surabaya. Retrived from http:///www.kbr68h.com. 26 Juli 2010.

2. Wicaksono, G. (2015). Mekanisme Corporate Governance dan Kemungkinan Kecurangan Dalam Pelaporan Keuangan. Skripsi Universitas Diponegoro Semarang.

3. Pernamasari, R. (2018). Implementation of Good Corporate Governance and Voluntary Disclosure Compliance: 100 compass indeks companies listed indonesia stock exchange (IDX) 2015-2016. Makalah disajikan pada. International Journal of Academic Research In Accounting, Finance and Management Sains. 8(2):235-249.

4. Utomo, S. T. (2017). Corporate Governance Dalam Mendeteksi Kecurangan Laporan Keuangan. Universitas Muhammadiyah Surakarta.

5. Kurniawati, E. (2012). Analisis Faktor-Faktor Yang Mempengaruhi Financial Statement Fraud 
Dalam Perspektif Fraud Triangle. Universitas Diponegoro.

6. Emirzon, J. (2007). Prespektif Hukum Bisnis Indonesia Pada Era Globalisasi Ekonomi.

7. Chtourou, S. M., Bedard, J., \& Courteau, L. (2001). Corporate governance and earnings management. University of Laval, Quebec, Canada.

8. Utomo, D., Kriek, M., Labbé, I., Conroy, C., \& Fumagalli, M. (2014). Simultaneous Modeling of the Stellar and Dust Emission in Distant Galaxies: Implications for Star Formation Rate Measurements. The Astrophysical Journal Letters, 783(2), L30.

9. Supriyono, M. (2008). Faktor-faktor risiko yang berpengaruh terhadap kejadian penyakit jantung koroner pada kelompok usia< 45 tahun (studi kasus di RSUP dr. Kariadi dan RS Telogorejo Semarang) (Doctoral dissertation, Program Pascasarjana Universitas Diponegoro).

10. Subandono, S. (2015). Pengaruh Independensi, Mekanisme Good Corporate Governance dan Kualitas Audit Terhadap Integritas Laporan Keuangan.

11. Bradbury, J. (2004). The Routledge companion to medieval warfare. Routledge.

12. Savitri, R. (2010). Pengaruh Mekanisme Corporate Governance Terhadap Ketepatan Waktu Pelaporan Keuangan: Studi Pada
Perusahaan Manufaktur Di BEI. Universitas Diponegoro Semarang.

13. Anderson, I. C., Campbell, C. D., \& Prosser, J. I. (2003). Diversity of fungi in organic soils under a moorland-Scots pine (Pinus sylvestris L.) gradient. Environmental Microbiology, 5(11), 1121-1132.

14. Brennan, N. M., \& McGrath, M. (2007). Financial statement fraud: Some lessons from US and European case studies. Australian Accounting Review, 17(42), 49-61.

15. Nguyen, V. P., Rabczuk, T., Bordas, S., \& Duflot, M. (2008). Meshless methods: a review and computer implementation aspects. Mathematics and computers in simulation, 79(3), 763-813.

16. Irawan, A., Razali, A. R., Ishak, W. W., Arshad, M. R., \& Yin, T. Y. (2015). Development of hexaquad robot: Modeling and framework. ARPN Journal of Engineering and Applied Sciences, 10, 17506-17513.

17. Ghozali, I. (2006). Aplikasi analisis multivariate dengan program SPSS.

18. Ghozali, I. (2011). Aplikasi Analisis Multivariate Dengan Program IBM.

19. Arshad, R., Razali, W. A. A. W., \& Bakar, N. A. (2014). Disclosure of Corporate Governance Structure and Financial Vulnerability. In Proceedings of World Business and Economics Research Conference. Auckland, New Zealand. 